\title{
Leipzig professor's death stirs bitter feeling
}

Munich. There was a tragic postscript last month to reunified Germany's policy of purging communist staff from universities in the former East Germany when Armin Ermisch, a professor of cell biology at the University of Leipzig who had consistently denied allegations of using his position as a member of the community part to the detriment of his colleagues and students, committed suicide.

Ermisch, who had also strongly denied charges of having ties to the Stasi, died only weeks after he had accepted a financial settlement in return for ending a three-year battle to retain his post at the university.

Along with nearly 1,000 colleagues in the state of Saxony, Ermisch was dismissed from his post in 1992 after a brief hearing by a committee, known as a Personalkommission, appointed by the science minister for the Land, Hans-Joachim Meyer. Using information from Stasi files and university colleagues, the committee decided Ermisch had abused his communist party links during the twenty years before the fall of the Berlin Wall (see Nature 359, 762; 1992).

After reunification, all university staff were required to submit themselves to examination by such Personalkommissionen, normally made up of public figures, academic colleagues and students, as well as one or two professors from west Germany. The fairness of these committees has frequently been challenged, many critics arguing that the lack of checks allowed personal grievances to influence their recommendations.

The final decision on all dismissals rests

with Meyer personally. Ermisch appealed against his own dismissal and, in the summer of 1993, won his case when a court found no evidence that he had abused his communist party links, and said that there were no grounds for dismissal.

But Ermisch did not get his job back. In the period after his dismissal, the entire university structure had been overhauled in line with reunification laws. Faculties were reorganized and streamlined, and all academic staff were required to reapply for their jobs in open competition. Staff numbers

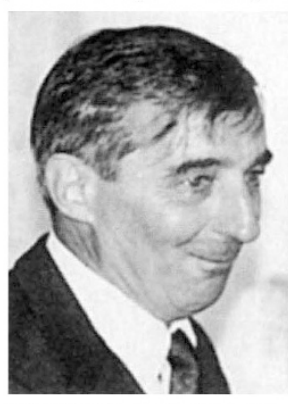

Ermisch: remembered as a brilliant teacher. were limited, and universities were entitled to dismiss superfluous staff within the restructured system.

Determined to complete the reunification process quickly, Meyer chose not to wait for the outcome of lengthy and numerous court appeals against individual dismissals, and during this process Ermisch's post had been filled. Ermisch appealed for reinstatement, and earlier this year, the court once again ruled in his favour, instructing the ministry to reemploy him. But the science ministry countered again with the argument that all vacancies had been filled.

According to Rainer Landgraf, a neurobiologist who was trained by Ermisch and now

\section{AIDS survey traces shifting attitudes}

Paris. French people are becoming increasingly aware of the risk of HIV transmission and changing their sexual behaviour as a result, according to a national survey on attitudes to AIDS.

The survey, which was conducted in November and December last year and is based on a random sample of 1501 individuals, confirms that the use of contraceptives is continuing to increase, particularly among the under-30s and single people. But more than a quarter of those people who have sexual relations with several partners say that they sometimes have unprotected sex.

Responses among the French population to the spread of HIV/AIDS involve a range of factors, however, in addition to the use of contraceptives. Some of those cited by respondents include screening tests by individuals and their partners, care over the selection of partners, and a reduction in the number of casual sexual partners, particularly among those over 30 years old and living as a couple.

This last factor marks a change when compared to previous surveys, and the finding remains to be confirmed, according to Nathalie Bajos of the French national institute for medical rseaech (INSERM). Further analysis should reveal whether this reduction in the number of casual partners is the result of bias in the responses of interviewees, or whether extra-marital relationships are perhaps becoming less acceptable to society.

The survey also reveals an ambiguous attitude towards those who are HIV-positive. While public tolerance towards infected individuals is growing, an increasing number of people favour coercive measures, such as obligatory screening or the creation of special medical centres to house them.

More than 80 per cent of those surveyed say that they are prepared to work, eat and go on holiday with someone who is seropositive. But almost the same number, 78.9 per cent, would like to see specialised medical establishments set up to take responsibility for patients infected with HIV.

Catherine Tastemain works at the Max Planck Institute for Psychiatry in Munich, Ermisch became very depressed when he finally accepted that he would never work again, and was forced to reach an out-of-court settlement. Landgraf has always supported Ermisch in his fight for justice. "Everyone remembers him as a great scientist and brilliant teacher," he says.

John Russell, head of the department of physiology at the University of Edinburgh, and a scientific collaborator of Ermisch, points out that Ermisch's frankness and honesty may itself have stimulated opposition within his faculty. Landgraf says that, as head of department, Ermisch never obstructed the careers of anti-communist colleagues, and judged them - albeit strictly - only on scientific grounds.

Another of Ermisch's supporters is WolfDietrich Arnold, head of the University of Leipzig's orthopaedic clinic, who, like Ermisch, successfully defended himself against charges of abuse of power. "The way Saxony has worked has been particularly harsh," says Arnold.

Candidates shortlisted for Arnold's job gave lectures in his department the day before the results of his first, successful, appeal were announced. After winning his second appeal, Arnold decided to abandon his fight and moved to a non-academic post in neighbouring Thüringen. He says that he regrets no longer being able to carry out research, but that "what hurts most is losing contact with students".

Ermisch's case is not an isolated one. More than 300 professors appealed against their dismissals on the basis of Personalkommissionen recommendations. Of the 250 cases that have reached conclusion, most, like Ermisch, finally accepted settlements. Twenty-five have won their appeals, but only a third of these have been given their jobs back.

The GEW, the trade union that represents German teachers, describes the situation as hopeless and unfair, pointing out that the newly appointed staff also now have employment rights. A GEW spokeswoman says that the state of Saxony must now work out how to obey court orders to reemploy academics judged to have been unfairly dismissed on the basis of Personalkommissionen recommendations. A major problem, she says, is that the state has been able to restrict itself to individual cases, as there is no collective movement to put pressure on government authorities.

The science ministry remains quiet on the issue, merely repeating that it has always followed the letter of the law, and that, if individual mistakes have been made, they do not outweigh the greater benefit of having quickly removed the powerful influence of communism from east German universities.

Alison Abbott 